\title{
The Contribution of Sport
}

\section{as a Means of Inclusion in Discussions of Sustainable Development for Visually Disabled People}

\author{
Ramon Pereira ${ }^{1}$, Renata Osborne ${ }^{2}$, \\ Soraia Izabel C. Cabral ${ }^{1}$, Carlos Alberto F. da Silva ${ }^{2}$ \\ ${ }^{1}$ Benjamin Constant Institute - Rio de Janeiro, Brasil \\ ${ }^{2}$ Salgado de Oliveira University - Niterói, Brasil
}

This study investigated how high-performance sport improved the quality of life and facilitated the inclusion of blind athletes in discussions about sustainable development at the Benjamin Constant Institute. It was also revealed that the blind still face discrimination, and that society associates the blind's visual disabilities with their other characteristics.

sustainability, participation, blindness

\section{Introduction}

Industry's unbridled development in an effort to gain wealth has caused the irreparable deterioration of natural resources and has endangered and compromised the ecosystem for generations to come. The subjugation of human beings by other humans has followed a similar path. With the exploitation of nature for the sake of profits, the corresponding erosion of social values has reinforced the idea that life favors only the strongest.

In response to this social and environmental problem, discourse about sustainability has emerged, with a variety of individuals giving multiple interpretations of issues related to the environment and social development (Lima 2003). The concept of sustainable development (SD) was created in the 1980s and gained international attention following the publication of Our Common Future, by the Brundtland Committee on Environment and Development in 1987, which defined SD as development capable of satisfying the needs of present generations without compromising the satisfaction or needs of future generations (United Nations Educational, Scientific and Cultural Organization [UNESCO] 2005).

The concept of SD contains ambiguities. Even when realizing the need for limits to achieve compatibility with ecological principles, SD maintains a belief in development as a means of meeting human needs, although these needs are not clearly defined. Moreover, we live in a world of polysemic and ambiguous language. Questions about SD, thus, rely more on critical reflections on the plurality of meanings and the construction of a temporary consensus in an effort to avoid ambiguous concepts (Freitas 2004).

Nevertheless, the concept has nonetheless survived much criticism. In 2005 UNESCO (2005) launched the Decade of Education for Sustainable Development (DESD), covering 2005-2014. In the documentation for this initiative it is stated that SD is the decisive goal of the relationship between 
man and nature and that the whole strategy of this restructuring project should be redefined by Education for Sustainable Development (ESD), an organization whose greatest challenge is to encourage behavioral change for a better world.

The final document of the international plan of implementation of the United Nations DESD describes this strategy as follows:

"This decade is based on the vision of a world where everyone has an opportunity to

benefit from education and learn the values, behavior and lifestyles required for a sustainable future and for the positive transformation of society" (UNESCO 2005, p. 17).

Although the ESD should benefit everyone, it is also important for everyone to participate in its construction. UNESCO (2005) shows concern for the marginalization of certain groups when local partners are mobilized to implement the DESD:

However, certain sectors of the population cannot be represented among such groups; marginalized groups like people with disabilities, very poor, nomads and migrants, ethnic and linguistic minorities, elderly and the chronically ill are often neglected and can become invisible. Special efforts, with adequate investment in human and material resources are necessary to ensure that the aforementioned groups participate in the ESD and share the benefits of the approaches and achievements of sustainable development (UNESCO 2005, p. 86).

In relation to people with disabilities, it has to be taken in account, as stated by the United Nations (2007), that this group represents $10 \%$ of the world population of whom $80 \%$ live in developing countries. As a result they need to be integrated and included in development activities, in order to ensure the Millennium Development Goals are achieved.

This need to integrate disabled people in development activities is not yet a reality. Persons with disabilities are also often excluded from comprehensive educational processes (George \& Duquette 2006, Ponchillia Armbruster \& Wiebold 2005) and inclusive education proposals. This problem has driven the research presented in this article.

Inclusive education, according to Obrusnikova and Block (2007), refers to an educational philosophy according to which the needs of students with disabilities should be met in regular schools. The authors highlight the United States as an exemplary case, where about $96 \%$ of students with disabilities are educated in mainstream schools.

Although we are in favor of inclusive education, the first listed author of this article is a teacher of the visually impaired at the Benjamin Constant Institute (IBC), which is a segregative system. IBC only serves the visually impaired and provides education to help them complete their basic education. In the 1990s the author observed that IBC athletes who completed their basic education continued their studies and their aspirations in life. They became outstanding professionals in their fields, differing from many of the IBC students from the previous decade who had abandoned their projects.

This period saw major changes in sport for the visually handicapped in Brazil, with a homologation of rules that focused on sports played by disabled people. Athletes' situations were improved by regulations that called for training that both was planned better, and that used methodologies appropriate to age and type of sport. Hygienic habits, organization, and independence were also stimulated and learned, clearly contributing to improvements in social relationships, selfesteem and, as a result, the quality of life of these athletes.

Among those responsible for this new national sport policy was the Brazilian Association of Sports for the Blind, now known as the Brazilian Confederation of Sports for the Blind, which changed the organization of national and regional championships. New requirements for compliance in each sport in the Brazilian Games facilitated a training process similar to the high-performance training practiced by sighted athletes. 
From this point on, IBC athletes began to think more effectively about their lives, becoming concerned about their future and their image. As a result they began to go to university and to compete in the labor market, no longer relying on the government's monetary benefits for the disabled.

In order to continue improving the quality of life for visually impaired people, this study, taking IBC athletes as an example, investigated the role of sport as a transformative factor in these athletes' lives, in accordance with the goals stated by the United Nations Decade for Sustainable Development.

The general aim of the study was to investigate visually impaired athletes' perspective of IBC and the extent to which high-performance sport has improved their quality of life, facilitated their inclusion in society, and enabled them to participate in discussions about SD.

The specific objectives were to investigate the following questions: a) how sport has promoted the inclusion of IBC's blind athletes; b) which period saw major changes in the athletes' behavior; c) what events between 1994-1998 motivated IBC athletes to continue with their achievements; d) what were the main differences between life before and after the athletes' practice of high performance sport; e) what are the benefits that the concept of SD has brought or will bring to their lives; and f) what is the role of the visually impaired in discussions about SD.

\section{Methods}

The research was qualitative and flexible, emergent rather than rigidly planned, and fundamentally interpretative, allowing the researchers to reflect on their role in the research process (Marshall \& Rossman 1999).

The research participants were visually impaired athletes who were selected according to their level of participation in training for high performance sport, their attendance and successful completion of basic school at IBC from 1994 to 1998, their continuation of studies, and their current level of satisfaction with their accomplishments.

Of the ten participating visually impaired athletes, seven had completed college education, two had completed high school, and one was completing university. They participated in associations for visually impaired people which compete in championships organized by the Confederation of Sports for the Blind since 1994 in swimming, athletics, football five, judo, chess and goalball (a sport specifically geared toward the visually impaired).

These athletes were in the B1, B2, and B3 classes. According to the International Sports Federation for the Blind, the visual classes recognized in official national and international competitions are: B1 - athletes with no perception of light in either eye, or with some perception of light but inability to recognize the shape of a hand at any distance or direction; B2 - athletes with the ability to recognize the shape of a hand up to visual acuity of $2 / 60$ and/or a visual field less than 5 degrees; and B3 - athletes with visual acuity from $2 / 60$ to $6 / 60$ and/or a visual field of between 5 and 20 degrees of vision in both eyes (Vieira, 2007).

After a pilot study, the data collection instrument was enhanced (Thomas, Nelson \& Silverman 2007) and consisted of a semi-structured interview guide (Alves-Mazzotti 2002) which allowed the planned questions to be complemented with other questions that arose during the interviews, thereby assisting in obtaining more effective responses to the questions proposed.

The research was guided by Brazilian National Health Council Resolution 196, dated October 10,1999 , which intends to ensure that research with human subjects is conducted in accordance with the principles of bioethics. In compliance with this perspective, the terms of consent, which explained important information about the research and participants' rights, were both printed on normal paper and in Braille out of respect for the autonomy of those involved. 
Interviews were conducted in the respondents' training environments, including gymnasiums, swimming pools, and athletic fields, though in areas where it was possible to hold interviews without any external distractions.

In order to maximize the study's reliability, a member check was used (Thomas, Nelson \& Silverman 2007). This is a process in which each respondent reads the transcript of their interview to confirm their statements.

Categories were established to analyze the data collected through interviews, in accordance with Gomes' guidelines (2002). This author explains that category refers to a concept which includes elements with common characteristics that relate to each other, and that they can be established prior to field work or can emerge from the data collection (or a combination of the two).

\section{Results}

\section{The power of sport in the lives of visually impaired athletes}

The initial responses of the participants related to the importance of sport in their lives, their lives before and after their involvement in high-performance sport, and their view of sport as a means of inclusion. All answered that sport was a very important factor in their lives. For them, sport had helped them out of inactivity and helped them to lose fear, to develop intellectually, to improve their notion of time and space, and to aid their orientation and mobility. Furthermore, sport improved their interpersonal relationships, self-esteem, motivation, and discipline. All of this allowed greater independence for them to come and go and gave them a sense of self-identity that distinguished them from the majority of the IBC students who did not have this opportunity.

In relation to their lives before and after their high-performance sport experience, they were all able to discern the differences between these two periods of their lives. Before this experience, they were anti-social, non-participatory, withdrawn, apathetic, dependent, and lacking ambition. Afterwards, they became more sociable, participatory, relaxed, confident, and independent as a result of their perceptions that they were equal to others and had expanded their horizons.

Participants declared that sport had effectively contributed to their sense of inclusion and emphasized their efficiency as opposed to their disability. Their experiences with sport served as a 'trampoline' for social inclusion, enabling them to approach the labor market, thus modifying images of suffering associated with the disabled. The participants felt a sense of social rehabilitation in their perception of equality between the disabled and the sighted. They also discovered an opportunity in citizenship to raise consciousness in society about the disabled and to act as a 'link' between the two.

\section{Quality of life}

When asked about quality of life, participants responded by defining it as follows: a) the ability to achieve a minimum of desired benefits, $b$ ) to be able to work and pay bills, c) to achieve everything with less difficulty, d) a notion created by the media, e) respect for public space, and f) longer moments of happiness. This question was followed with another related to the quality of their own lives. They replied that they had the following: a) a better quality of life than in the past, b) a good quality of life that they are striving to improve, c) a quality of life that is not ideal, and d) a good quality of life that is improving because of sport.

Participants were also asked what would be important to them in terms of a good quality of life. Among their responses were independence in the environment where they lived, to be considered as citizens, to have motivation to always improve, to be included in society, and to live closer to work and their place of training.

Also questioned in the study was whether sport contributed to a good quality of life. The respondents replied that sport contributed to overcoming shyness, improved interpersonal relationships 
and motivation, provided encouragement to study in regular institutions, and resulted in social inclusion.

\section{Visually impaired people's perspectives of sustainable development}

The investigation of respondents' knowledge of sustainable development (SD) showed that $60 \%$ were unaware of the term. Before the interviews, therefore, the respondents were given a brief explanation of sustainable development.

After this respondents were asked to relate SD to sport. They replied that sport motivates the visually impaired to demand improvements in social interactions, that it provides a way for them to exercise citizenship by promoting respect for people and the environment, that it offers social interaction, and that it facilitates participation in solving collective problems in the search for an ideal. All of this contributes to the SD proposal.

In relation to the participation of visually impaired people in discussions about SD, the respondents answered that the visually impaired can and should be included because they are efficient citizens and not handicapped in what they do, that they have much to learn and much to contribute to discussions about their habitat, and that disabled people do not always expect solutions to their problems from society without helping to search for solutions. In other words, the participation of the disabled is essential in the making of decisions about questions that concern them.

Regarding questions about their own participation in SD discussions, the respondents answered that they could contribute by offering socializing strategies, by showing the basic needs of the visually impaired in terms of accessibility, inclusive education and transportation, and by demanding reductions in noise pollution, which causes difficulties in orientation for the visually impaired.

\section{Discussion}

As shown by the results, sport was essential to the process of change in the lives of the visually impaired. It also offered crucial physical benefits such as exercise of the cardiovascular system, gains in muscular strength, and improved coordination, balance, and mobility, all of which allow greater independence in their daily lives (Urzanqui 1995, Capella-McDonnall 2007, Holbrook, Caputo, Perry, Fuller \& Don 2009). The participants, however, emphasized the psychological and social benefits of sport over the physical ones.

Physical activity is seen as a means of developing the sort of self-confidence so weakened in the visually impaired. Through collective exercise they can overcome their shyness, develop their ability to solve problems, and find motivation to accomplish new tasks (Guaragma, Pick \& Valentini 2005, Ponchilia, Ambruster \& Jennipher 2005, Vieira 1998). Capella-McDonnall (2007) and Holbrook et al. (2009) describe the practice of physical activity as essential to the proper development of the visually impaired, as it promotes physical, emotional, and social health.

The participants changed their attitudes and lifestyles and began to see themselves as equals to the sighted. They overcame the disabled label because sport provided them with an opportunity to show their efficiency and not their disability. A study (Nunes 1998) in which mentally handicapped individuals in a specialized institution were interviewed found that the self-image of the disabled was clearly undervalued and was directly linked to their perception of how 'others' viewed them. The author states that they demonstrated full awareness of the prejudice and social stigma of which they were victims.

Goffman (1988) explains that different kinds of stigma exist; however, they have the same sociological characteristics: an individual that could be easily accepted in daily social relationships has a trait that draws attention, and destroys the possibility of attention being paid to their other attributes. People tend to infer a number of imperfections that do not exist from the original imperfection. The author cites Gowman who explains that some people generalize vision disability as a gestalt of 
incapacity, so that an individual shouts at a blind person as if they were deaf, or tries to help a blind person stand as if they were crippled.

Society is still unprepared for the inclusion of disabled people (Robertes 1996, Carvalho 2004, Kirchner 2006). Robertes (1996) refers to common occurrences in conversations including the sighted and blind in which the sighted ask for information about the blind by addressing their sighted companions as opposed to asking them directly. Goffman (1988) explains that people believe that a person with a stigma is not completely human. Based on that assumption, people discriminate in many ways thereby reducing the life chances of stigmatized persons.

Robertes (1996) reports that the terms efficiency and disability are related to the interests of society, and to the capitalist system of production in particular. He describes efficient people as those who carry out their professional functions in a consistent manner and disabled people as those who are nonproductive. Words such as normal, abnormal, disabled, and efficient, Robertes implies, carry cultural values developed by society.

The experiences of visually impaired athletes in this study demonstrate the role of sport in changing their images as victims, contributing to their full development, and enabling the disabled to enjoy a social life. Through their lives these athletes show their skills. Effective participation in the social environment in which they live creates an 'efficient and not disabled' path; the examples allow for a better education in our society for the inclusion of this segment. As explained by Goffman (1988), when there is a continuum in social interaction, certain stigmas begin to gradually subside.

Quality of life is a comprehensive and complex issue that pertains to a society's culture (Devide 2002, Minayo, Hartz \& Buss 2000). Quality of life is also subjective, emerging from the personal histories of individuals, and varies depending on what they value in their daily lives. This subjectivity makes the study of each social group's ideals worthwhile (Devide 2002). In this 'daily life' sense, the research participants related quality of life with studying in regular institutions, work, moments of happiness, independence, being included, respect for public space, and living closer to the sites that they frequented in their daily lives. These characteristics all relate to the particular difficulties facing this group and its ability to succeed.

Sport is considered by the United Nations to be a powerful vehicle worthy of further exploration, not for the purpose of creating new champions or promoting sport, but as a means of integration with other comprehensive activities to achieve development and peace. In serving as a method for promoting education, health, development, and peace (United Nations 2003), sport also plays a role in the Decade of Education for Sustainable Development in harmony with international initiatives such as the Millennium Development Goals, the Education for All movement and the United Nations' Literacy Decade. All of these initiatives aim to improve quality of life, especially for the most marginalized, and stress the importance of high quality basic education (UNESCO 2005).

The participation of people with disabilities in discussions about sustainable development is important because this group should not expect solutions to their problems to be presented by society, but must participate in building these solutions.

Similarly the United Nations Convention on the Rights of Persons with Disabilities (2006) emphasized "the importance of mainstreaming disability issues as an integral part of relevant strategies of sustainable development" (p. 1), and that the disabled should be actively involved in decision-making about policies and programs, including those directly concerning themselves.

The research participants presented some specific agenda items for sustainable development, each of which relate to their daily difficulties, such as accessibility, inclusive education, and the reduction of noise pollution.

In relation to noise pollution, research was recently conducted (Emerson \& Sauerburger 2008) among visually impaired people to evaluate the strategy of crossing a street when the environment is quiet. This is a strategy, still used today, that was developed in the 1940s when cars were noisier. 
Because sound levels generated by cars have since been reduced, the research investigated the current usefulness of that strategy. The results of the study demonstrate the importance of an environment that is as quiet as possible so that the disabled can detect the traffic and cross the street safely. Other parameters, though, apart from the environmental sound level, are also important for guiding the visually impaired, and each situation must be analyzed individually.

\section{Conclusion}

Sport, an important factor in the lives of the athletes interviewed, led to improvements not only in self-esteem and motivation, but also in the cultivation of virtues that facilitate the social integration of any person, disabled or not.

In addition to their usefulness in demonstrating efficiency as opposed to disability, facilitating equality for all, and giving the disabled independence while teaching them how to help, the primary goal of high-performance sport is the exercise of citizenship.

It is important to note that blind people cry out for social justice and rights and resolutions for the visually impaired through their own representatives, who must be heard and respected. They do not want to be labeled as incapable and helpless, and do not want to wait for solutions from society.

The disabled population is growing every second as a result of genetic problems or diseases acquired before, during, or after birth. Although some authors (Brancatti, Viana \& Vilela 2001, Cratty \& Theresa 1994, Guaragma, Pick \& Valentini 2005, Vieira 1998, Moira, Lieberman \& Karen 2006) present sport as a major contributing factor to the socialization of the disabled, we argue that sport is the only means of access to social inclusion for the visually impaired.

This study recommends further research into the inclusion of the visually impaired segment for the sake of providing opportunities for them to present their problems, to give them a voice in claiming their own solutions, and to legitimize them as citizens. It was thus intended to present a trajectory of an improvement in quality of life as experienced by IBC athletes. We believe that the potentialities of the visually impaired may be continually developed in intelligent ways, despite their absence of vision.

Sport, in conclusion, leads to achievement in citizenship and teaches respect for others. It should also serve as a means of education for all, whether disabled or not. It can serve as a tool for personal development that enables practitioners to find the skills necessary to harmonize with the social world.

\section{REFERENCES}

Alves-Mazzotti, A.J. (2002). O planejamento de pesquisas qualitativas /The planning of qualitative research/. In A.J. Alves-Mazzotti \& F. Gewandsznajder (Eds.), O Método nas Ciências Naturais e Sociais /The method in the natural and social sciences/ (pp. 147-178). São Paulo: Thompson.

Block, M.E. \& Obrusnikova, I. (2007). Inclusion in Physical Education: a review of the literature from 19952005. Adapted Physical Activity Quarterly, 24, 103-124.

Brancatti, P.R., Viana, É.S. \& Vilela, R.C.A. (2001). Atividade física adaptada: possibilidade de acessibilidade /Adapted physical activity: possibility of access/. In Congresso Brasileiro de Atividade Motora /Brazilian Congress of Motor Activity/: vol. 6. (pp. 112-122). Paraná: Universidade Estadual de Londrina/Londrina State Universidade/.

Capella-McDonnall, M. (2007). The Need for Health Promotion for Adults Who Are Visually Impaired. Journal of Visual Impairment \& Blindness, 101, 133-145.

Carvalho, R.E. (2004). Educação Inclusiva: com os pingos nos "is" /Inclusive Education: putting the record straight/. Porto Alegre: Mediação.

Cratty, J.B. \& Theresa, A.S. (1984). La imagem corporal de los ninôs ciegos / The body image of blind children/, International Council for Education of the Visually Handicapped/. Argentina-Córdoba: Región Latinoamericana.

Devide, F.P. (2002). Educacão Física, Qualidade de Vida e Saúde: campos de intersecção e reflexões sobre intervenção. /Physical Education, Quality of Life and Health: fields of intersection and reflections on intervention/. Revista Movimento, 8, 102-112. 
Emerson, R.W. \& Sauerburger, D. (2008). Detecting approaching vehicles at streets with no traffic control. Journal of Visual Impairment \& Blindness, 102, 747-760.

Freitas, M. (2004). Desenvolvimento Sustentável /Sustainable Development/. Perspectiva, 22, 547-575.

George, A.L. \& Duquette, C. (2006). The Psychosocial Experiences of a Student with Low Vision. Journal of Visual Impairment \& Blindness, 100, 152-163.

Goffman, E. (1998). Estigma: notas sobre a manipulação da identidade deteriorada /Stigma: Notes on the Management of Spoiled Identity/. Rio de Janeiro: Guanabara Koogan.

Gomes, R. (2002). A análise de dados em pesquisa qualitativa /Data analysis in qualitative research/. In M.C.S. Minayo (Ed.), Pesquisa social: teoria, método e criatividade/Social research: theory, method and creativity/ (pp. 67-80). Petrópolis: Vozes.

Guaragna, M.M., Pick, R.K. \& Valentini, N.C. (2005). Percepção de pais e professores da influência de um programa motor inclusivo no comportamento social de crianças portadoras e não-portadoras de necessidades especiais. /Perceptions of parents and teachers of the influence of an inclusive motor program on the social behavior of children with and without special needs/. Revista Movimento, 11, 89-117.

Holbrook, E., Caputo, J., Perry, T., Fuller, D.K. \& Don, W.M. (2009). Physical Activity, Body Composition, and Perceived Quality of Life of Adults. Journal of Visual Impairment \& Blindness, 103, 17-29.

Kirchner, C. (2006). Seize the Moment! Establishing Vision-Related Rehabilitation and Access in the Nation's Public Health Policy Agenda. Journal of Visual Impairment \& Blindness, 100, 780-792.

Lima, G.C. (2003). O discurso da sustentabilidade e suas implicações para a educação /Sustainability discourse and its implications for education/. Ambiente \& Sociedade, 6, 99-119.

Marshall, C. \& Rossman, G.B. (1999). Designing qualitative research. (3rd ed.). Thousand Oaks: Sage.

Minayo, M.C.S., Hartz, Z.M.A. \& Buss, P.M. (2000). Qualidade de Vida e Saúde: um debate necessário /Quality of Life and Health: a necessary debate/. Revista Ciência e Saúde Coletiva, 5(1), 7-18.

Moira, E.S., Lieberman, L. \& Karen, E.H. (2006). Beliefs About Physical Activity Among Children Who Are Visually Impaired and Their Parents. Journal of Visual Impairment \& Blindness, 100, 223-234.

Nações Unidas (2003). Esporte para o desenvolvimento e a paz: em direção à realização das metas de desenvolvimento do milênio/. Sport for development and peace: towards achieving the millennium development goals/. Retrieved November 28, 2008, from http://www.esporte.gov.br/publicacoes.

Nunes, L.R.O.P. (1998). Auto Percepção /Self Perception/. In R. Glat, J.R. Ferreira \& E.G. Mendes (Eds.), Pesquisa em Educação Especial na Pós-Graduação/Research in Special Education at the Post-Graduate Level (pp. 48-125). Rio de Janeiro: Viveiros de Castro.

Ponchilia, P., Ambruster, J. \& Jennipher, W. (2005). The National Sports Education Camps Project: Introducing Sports Skills to Students with Visual Impairments through Short-term Specialized Instruction. Journal of Visual Impairment \& Blindness, 99, 685-695.

Robertes, R. (1996). Deficiência de quem? /Whose disability?/. Revista Discorpo, 6, 17-27.

Thomas, J.R., Nelson, J.K. \& Silverman, S.J. (2007). Métodos de Pesquisa em Atividade Física /Research Methods in Physical Activity/ (5 ${ }^{\text {th }}$ ed.). Porto Alegre: ArtMed.

United Nations Educational, Scientific and Cultural Organization (2005). Unesco. United Nations decade of education for sustainable development 2005-2014: Draft International Implementation Scheme. January 2005. Retrieved may 11, 2001, from http://portal.unesco.org/education/admin/.

United Nations (2006). Conventional on the Rights of Persons with Disabilities and Optional Protocol. Retrieved September 15, 2001, from http://www.un.org/disabilities/documents/convention/convoptprot-e.pdf/.

United Nations (2007). Economic and Social Council. Mainstreaming disability in the development agenda. Retrieved September 15, 2001, from http://www.un.org/disabilities/default.asp?id=358/.

Urzanqui, A. (1995). Psimotricidad, deficiencia visualy y deporte. /Psicomotricity, visual disability and sport/. Revista Blind Sport International, 9, 52-98.

Vieira, C.S. (1998). Influência da Prática do Judô no Comportamento Ansioso de Adolescentes Deficientes. /Influence of the Practice of Judo on Anxious Behavior of Adolescents with Disabilities/. Unpublished master's thesis. Rio de Janeiro: Rio de Janeiro State University.

\section{AUTHOR'S ADDRESS: $\quad$ Renata Osborne}

Rua Jangadeiros 37 apto 701

Ipanema, Rio de Janeiro - RJ

cep 22420-010 Brazil

Email: renataoc@oi.com.br 